DOI 10.18551/rjoas.2019-09.12

\title{
MEASURING COMPETITIVE ADVANTAGE OF PALM OIL INDUSTRY IN INDONESIA USING THE STRUCTURE CONDUCT PERFORMANCE PARADIGM
}

\author{
Othman Lie ${ }^{*}$, Raharja Sam'un Jaja, Maulina Erna, Muftiadi Anang \\ Department of Business Administration, University of Padjadjaran, Bandung, Indonesia \\ *E-mail: othmanlie@gmail.com
}

\begin{abstract}
Market for products made of palm oil and its derivatives have been on the rise. This is a good chance for the industry of palm oil tree plantations in Indonesia especially in Riau Province to advance their competitive qualities in order to achieve maximum economic performance. Augmentation of competitive quality is determined by company's ability to implement price strategy, product differentiation, innovation, and research and development. This study conducted to finding the market structure model, behavior and performance of palm oil plantation companies in Riau Province in Indonesia. This study uses the Structure-ConductPerformance approach. Observations have been made in the industry of palm oil in Riau Province producing CPO. This is a descriptive-explorative study with data collection technique of in-depth interviews on selected informants. Data analysis is carried out with statistics in two stages: first, normality test and second, correlation test. The normality test method used in this research is the Kolmogorov Smirnov method meanwhile the correlation method used here is the Spearman's rho correlation method. Additionally, the Spearman's rho is suitable for data with number of observations less than 30 . Based on the results of the normality test by using the SPSS v.20, it is found that the highest correlation is the structure variable with behavior. All the correlations have positive direction showing that there is a oneway correlation between the structure, behavior, and performance variable. This means that if structure increases, the behavior increases. If behavior increases, the performance progresses, and vice versa.
\end{abstract}

\section{KEY WORDS}

Competitive advantage, structure, conduct, performance, palm oil industry.

Companies are now in the industrial revolution era 4.0 (Almada-Lobo, 2016; Lasi, Fettke, Kemper, Feld, \& Hoffmann, 2014) as marked by the implementation of the artificial intelligence and overabundance of digital innovations which occur exponentially fast. Any change because of this has direct impact on the economy, industry, governance, and even global politics (Kraciuk, 2018; Stock \& Seliger, 2016). The implementation of the industry 4.0 opens up vast positive competition that is more competitive in Indonesia. This condition helps increase productivity and innovation, reduces operational cost, and increases efficiency leading to increase in domestic product exports (Febrian, Maulina, \& Purnomo, 2018; Mukherjee, Kamarulzaman, Shamsudin, \& Latif, 2015; Obado, 2008).

One of the industries becoming the center of attention and focus is the industry of palm oil trees. Most of the products of palm oil in Indonesia are export commodities. The target market of palm oil exports until 2012 reaches $60 \%$ of the total production. India is the main export destination of Indonesian palm oil, comprising $47.09 \%$ of the total palm oil exports, followed by Malaysia of 13,9\%, and Holland of $10.05 \%$ (Dirjenbun, 2015). Production segment of Indonesian Crude Palm Oil (CPO) in the international market shows an increasing trend. Total production of world's palm oil in 2014 is $46.7 \%$ of the total tons, in which Indonesia and Malaysia hold $85.22 \%$ of the world's palm oil production. The segment of the Indonesian CPO is 22.1 million tons, while the Malaysian CPO is 17.7 million tons.

Indonesia is far more superior in terms of CPO exports. But in terms of the palm oil downstream industry, Indonesia loses insufferably to Malaysia. Since 1996, Malaysia has been developing its palm oil downstream industry capable of producing downstream palm oil products which have high value added compared to the activities of exporting CPO (Rasiah 
\& Shahrin, 2006). By considering the condition of the competition, it is important to understand palm oil and its derivative competitiveness in the market structure in Indonesia and then to formulate strategies to further develop Indonesia's palm oil industry in order to increase its competitiveness.

Capron \& Hulland (1999) and Chaiprasit \& Swierczek (2011) state that the palm oil industrial environment in this current industrial era is faced with globalization with a very tough competition. The segment of the biggest production of Indonesia's palm oil is from 6 provinces contributing $73.69 \%$ of the total production. Based on the information from The Center of Agricultural Data and Information System of Secretariat General of Ministry of Agriculture (2016), Riau Province and North Sumatera Province have the biggest segment of production center of CPO in Indonesia contributing $23.75 \%$ and $16.24 \%$ respectively. The second biggest are Central Kalimantan Province (10.96\%), South Sumatera Province (9.76\%), West Kalimantan Province (6.60\%), and Jambi (6.39\%).

Directorate General of Plantation (Dirjenbun, 2016) states that the total area of palm oil tree plantations in Indonesia is $11,914,499$ hectares producing $3,229,381$ tons of CPO. Of all the total area of the plantations, $15 \%$ or 1.9 million hectares is located in Riau Province. With that all in mind, palm oil trees become a commodity that has a very important role in the national economy especially as the major source of the vegetable oil, as a creator of countless jobs, and as sources of income and national income. That important role becomes the reason that places the palm oil tree industry to be a very important industry to Indonesia's economy (Obado, 2008).

The push that all palm oil processing companies experience is to be competitive and superior (Rasiah \& Shahrin, 2006). The number of the companies has an influence on the market concentration in this industry. The more concentrated the market structure, the bigger the market power that will be achieved (Kaur \& Mantok, 2015; Loecker \& Goldberg, 2013). The level of the market concentration is unparalleled to the level of the competition. This is due to the fact that the market concentration pushes the companies to have a collusion (Smith, 2008)

According to Weiss (1979), Porter (1985) and Hoskisson et al. (1999), industry competitiveness can be seen from several angles. One of the fundamental frameworks in the industrial economy analysis is the relationship or correlation between structure, conduct, and performance (structure-conduct-performance) (Bain, 1951; Becker, 2014; Schmalensee, 1989; Weiss, 1979). The simplest correlation of the three variables is the linear correlation in which the structure influences conduct and then influences performance (Schmalensee, 1989; Weiss, 1979). In this structure-conduct-performance (SCP) the correlation between the three influences other factors including technology, progressivity, strategies and efforts to encourage sales (Bain, 1951).

The SCP paradigm (Bain, 1951) assumes that there is a mutually influencing correlation between the structure, conduct and performance of a company in the industry (Bain, 1951). Figure 1 shows the linier structure-conduct-performance correlation (SCP) of a company.

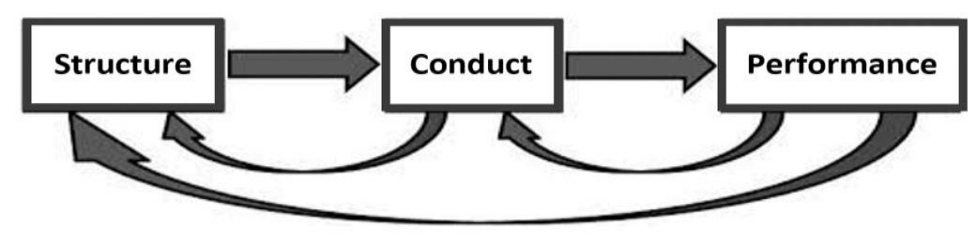

Figure 1 - The SCP model

The SCP in analyzing the industry's economy is by stating that a company in such a market has a power of monopoly. In the view of the SCP (Bain, 1951), the main hindrance to an effective function and conduct strategy of a company towards another company is by not allowing another company to compete. By applying these behavior strategies, a company can gain and use its power to control its products and their prices (Weiss, 1979). The 
implication of this notion is that the government can implement a competition policy. The most serious hindrance that a market faces is the strategic behavior of several companies to not allow other companies to compete on a certain level (Bain, 1951; Becker, 2014; Kim, Lee, Yu, Kim Jean Lee, \& Yu, 2004; Schmalensee, 1989).

According to Bain (1951) and Schmalensee (1989), the basic condition in an economy will be the foundation of the formation of competitiveness or be the cause of the development of the market structure in an industry. The diagram regarding competitive structure in an industry in Figure 2 below elaborates the basic condition in competitiveness.

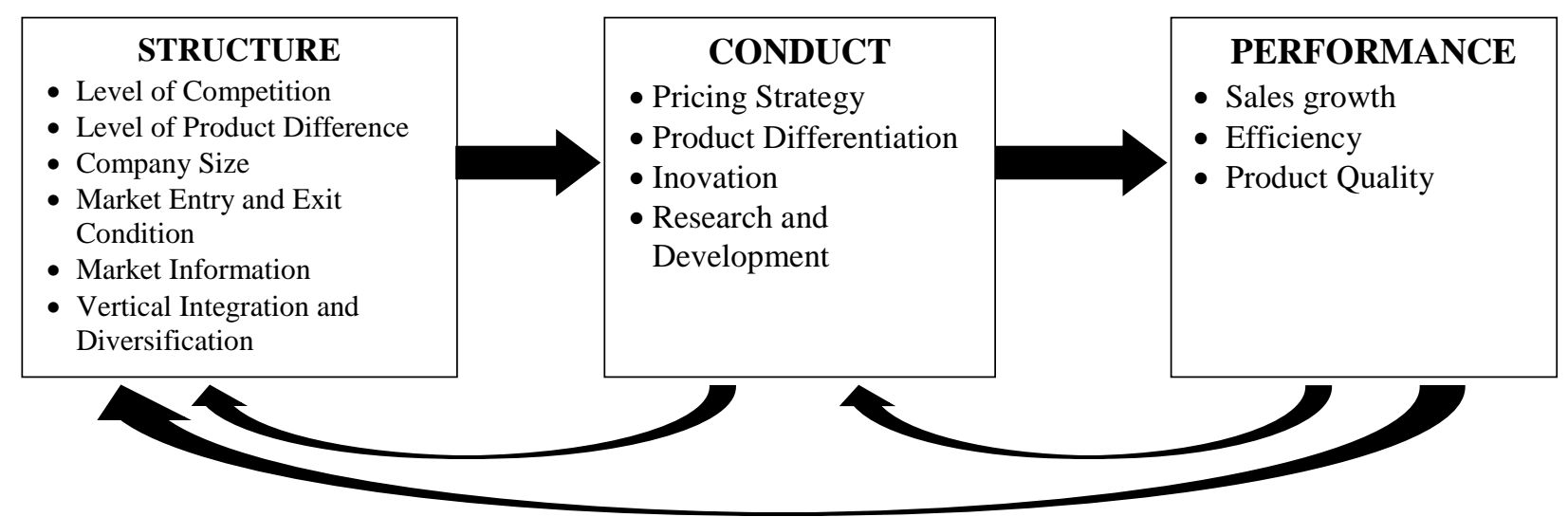

Figure 2 - The Structure-Conduct-Performance Framework

The structure of a market will have influence on companies' behavior in the market which simultaneously determines the performance of the market system as a whole (Weiss, 1979). The performance of an industry is measured by among others the value added, degree of innovation, efficiency and profitability. The concept of the relationship between behavior and performance structure explains how a company will behave to deal with a certain market structure in an industry (Weerawardena \& Mavondo, 2011). From that behavior will emerge a kind of performance in which the structure and behavior will influence performance.

Considering the importance of the national palm oil plantation industry and condition of the industry's competitiveness at the moment, an in depth analysis regarding the market structure, company's behavior and performance of the palm oil industry in Riau Province. This is based on the suggestion from the result of the previous research (Bain, 1951, 1986; Becker, 2014; Hoskisson et al., 1999; Schmalensee, 1989; Weiss, 1979). The purpose of this research is to find out the shape of the structure of the industry, behavior and performance of the companies in the palm oil industry in Riau Province.

\section{METHODS OF RESEARCH}

This research focuses on the structure, behavior and performance of the companies in the palm oil industry in Riau Province. The research method used is the qualitative method with in depth exploration (Gunawan, 2013) on the research object of an analysis of the structure of the industry, behavior and performance of the companies in the palm oil industry in Riau Province. The qualitative method is selected as it is oriented at data mining from professional individuals in a natural setting as described by (Musianto, 2002) that it can guide through an unexpected finding before and expected to create a new theoretical framework especially in relation to the structure, behavior and performance (Bain, 1951) in the palm oil industry.

The informant selection process up to the last informant is based on the snowball sampling until saturated and accurate data is achieved. The informants in this research are (1) Head of Indonesian Palm Oil Association of Riau or Gabungan Pengusaha Kelapa Sawit Indonesia (GAPKI) Riau; (2) Director or owner of palm oil plantation company; (3) Head of 
State Crops Office of Riau Province. The selection of companies which are determined as sources of information is made by applying several criteria; (1) The company has license and legal entity; (2) The company owns a pal oil plantation located in the region of Riau Province; (3) The company owns a palm oil mill or pabrik kelapa sawit (PKS) in the region of Riau Province; (4) The company has employees of at least 30 or more; (5) The company produces CPO; (6) The company owns a certificate of Indonesian Sustainable Palm Oil System (ISPO). The number of the selected informants is 9 palm oil plantation companies operating in the region of Riau Province, Indonesia.

Data analysis is performed statistically through two stages. First stage is normality test and second stage is correlation test. The method of normality test used in this research is the Kolmogorov Smirnov method (Lilliefors, 1967) by using the SPSS v.20 software. The correlation method used here is the Spearman's rho correlation method (Hauke \& Kossowski, 2011). In addition, the Spearman's rho correlation method is suitable for fewer data, with only 9 informants. The evaluation of correlation strength or level can be seen in Table 1.

Table 1 - Correlation coefficient level

\begin{tabular}{|c|c|}
\hline Correlation coefficient & Correlation strength \\
\hline $0.000-0.199$ & Very low \\
\hline $0.200-0.399$ & Low \\
\hline $0.400-0.599$ & Medium \\
\hline $0.600-0.799$ & Strong \\
\hline $0.800-1.000$ & Very strong \\
\hline
\end{tabular}

The analytical stage through statistics is done through two stages, the normality test and the correlation test. The first stage, the normality test is to assume that the data that will be analyzed form a normal distribution (Sugiyono, 2010). The normality test on the data retrieved by the researcher is by using the Kolmogorov Smirnov technique, with the interpretation that if the p-value (sig) score higher than 0.05, it means that the data have a normal distribution/are normally distributed; meanwhile if the p-value (sig) score is lower than 0.05 , it means that the data do not have a normal distribution/are not normally distributed.

\section{RESULTS AND DISCUSSION}

Based on the normality test by using the SPSS v.20 software, a result says that of the 13 indicators that are researched (competitive level, product differentiation level, company size, in and out condition, market information, vertical integration and diversification, pricing strategy, product differentiation, innovations, research and development, sales growth, efficiency, product quality) there are 2 indicators that have a normal distribution/are distributed normally and they are the competitive level indicator (in the structure variable) and the product differentiation indicator (in the performance variable); meanwhile the other 11 indicators are not normally distributed/do not have a normal distribution causing the use of the correlation method of the Spearman's rho correlation method. In addition, this Spearman's rho is suitable to use for data the number of the observed less than 30 .

The second stage is the correlation test. This test is done to find out if there is or not a correlation, and if there is, how close the correlation and if it is meaning or not, and if the significance value is $<0.05$ the data are correlated, and if it is $>0.05$ the data are not correlated/have no correlation. If the produced $r$ is negative $(-)$, the formed correlation is inversely proportional, and if the produced $r$ is positive $(+)$, the formed correlation is directly proportional. The gained result from the correlation analysis is the direction of the correlation and the correlation coefficient describing the correlation strength of the two indicators or two variables that are observed.

One of the new approaches focusing on the improvement of the company's competitiveness when it faces dynamic and uncertain competition dynamics is the structureconduct-performance (SCP) model. This research is referring to the research results gained 
by Bain (1951), (1986); Weiss (1979); Schmalensee (1989); Hoskisson et al. (1999) and Becker (2014). In general, a company leans to be more superior than its competitors that with this SCP, the industry can explore any market opportunity and create competitive superiority (Teece, Pisano, \& Shuen, 1997).

Nine palm oil companies are used as informants in this research and they are PT. Eka Dura Indonesia, PT. Hutahaean, PT. Tri Bakti Sarimas, PT. Air Jernih, PT. Swastisiddhi Amagra. PT. Multi Sawit Ekanisura, Asosiasi Petani Sawit Swadaya Amanah, Koperasi Unit Desa Sawit Jaya, and PT. Perkebunan Nusantara V. After performing in depth interviews with selected informants namely the director or the owner of each company, the correlation test was conducted among the variables of structure, behavior and performance of each company.

Table 2 - Correlation among variables of Structure, Behavior and Performance

\begin{tabular}{|c|c|c|c|}
\hline Variable & Correlation & \multicolumn{2}{|c|}{ Conclusion } \\
\hline Structure and Behavior & 0.826 & Positive & Very Strong \\
\hline Behavior and Performance & 0.547 & Positive & Medium \\
\hline Structure and Performance & 0.438 & Positive & Medium \\
\hline
\end{tabular}

Based on Table 2, the highest correlation is between the two variables of structure and behavior, followed by behavior and performance and then structure and performance. All correlations have positive direction showing that there is a one directional correlation between the variables of structure, behavior, and performance. This means that if structure improves, behavior will improve, and if behavior improves, performance will improve, and vice versa.

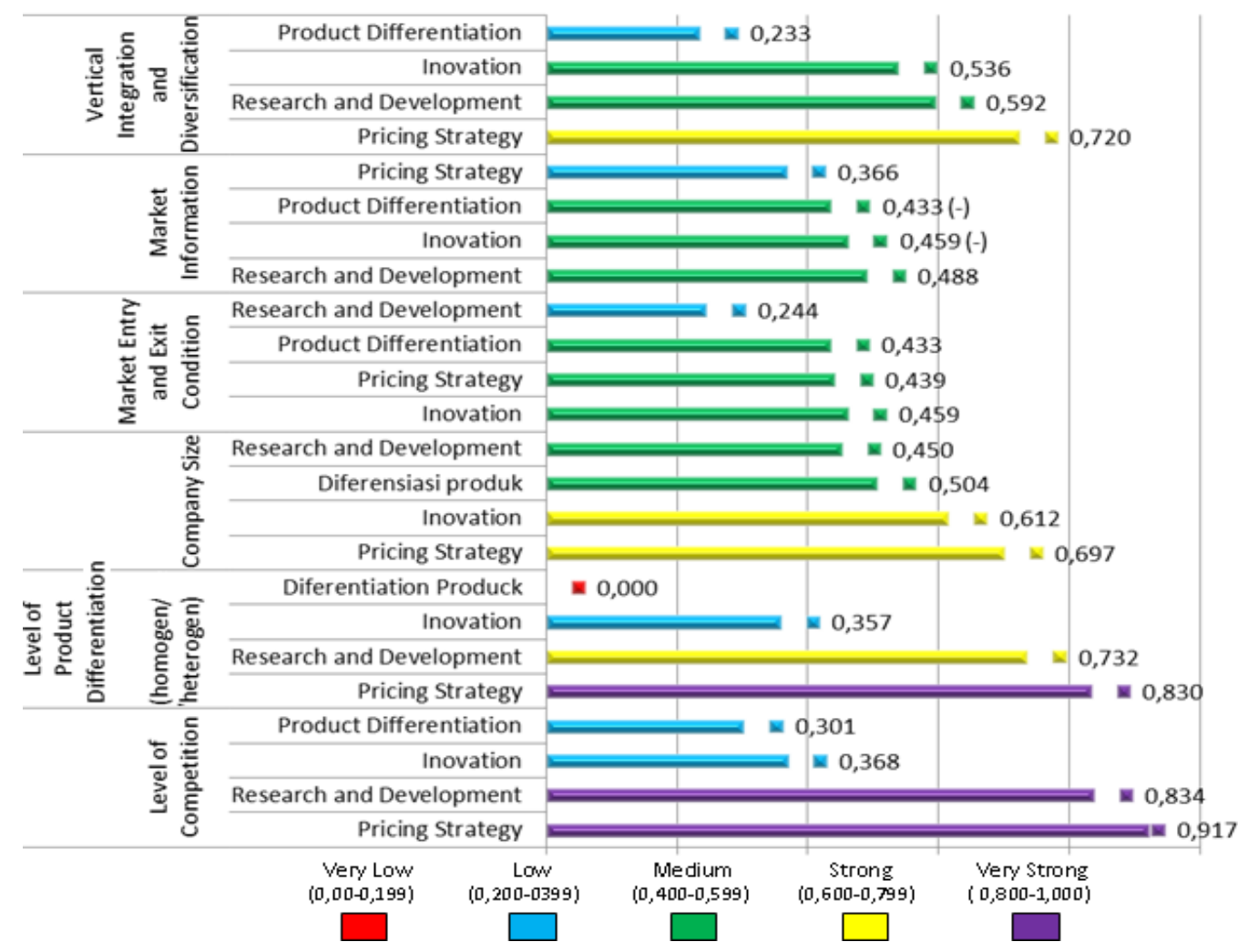

Figure 3 - Correlation between Indicators in Variables of Structure and Indicators in Variables of Behavior

To find out which indicator contributes the highest in each variable, Figure 3 shows summary of the coefficient correlation of each indicator. Based on fig. 3, the strongest correlation is that between the indicators of competitive level (in variables of structure) and 
indicators of price strategy as well as indicators of research and development (in variables of behavior) followed by correlation between indicators of level of product differentiation (homogenous/heterogeneous) and indicators of price strategy (in variable of behavior) and the lowest is correlation between indicators of level of product differentiation (homogenous/heterogeneous) (in variables of structure) and indicators of product differentiation (in variables of behavior).

The next analysis is on the correlation between the indicators in the variables of behavior and indicators in the variables of performance. Based on Figure 4, the strongest correlation is that between the indicators of product differentiation (in the variables of behavior) and the indicators of product quality (in the variables of performance) and the correlation between the indicators of research and development (in the variables of behavior) and the indicators of efficiency (in the variables of performance).

Meanwhile the lowest correlation is that between the indicators of product differentiation (in the variables of behavior) and the indicators of efficiency (in the variables of performance). As for the lowest correlation category is the correlation between the indicators of price strategy and the indicators of research and development (in the variables of behavior) and the indicators of product quality (in the variables of performance), the correlation between the indicators of research and development (in the variables of behavior) and the indicators of product quality (in the variables of performance) as well as the correlation between the indicators of product differentiation (in the variables of behavior) and the indicators of efficiency (in the variables of performance).

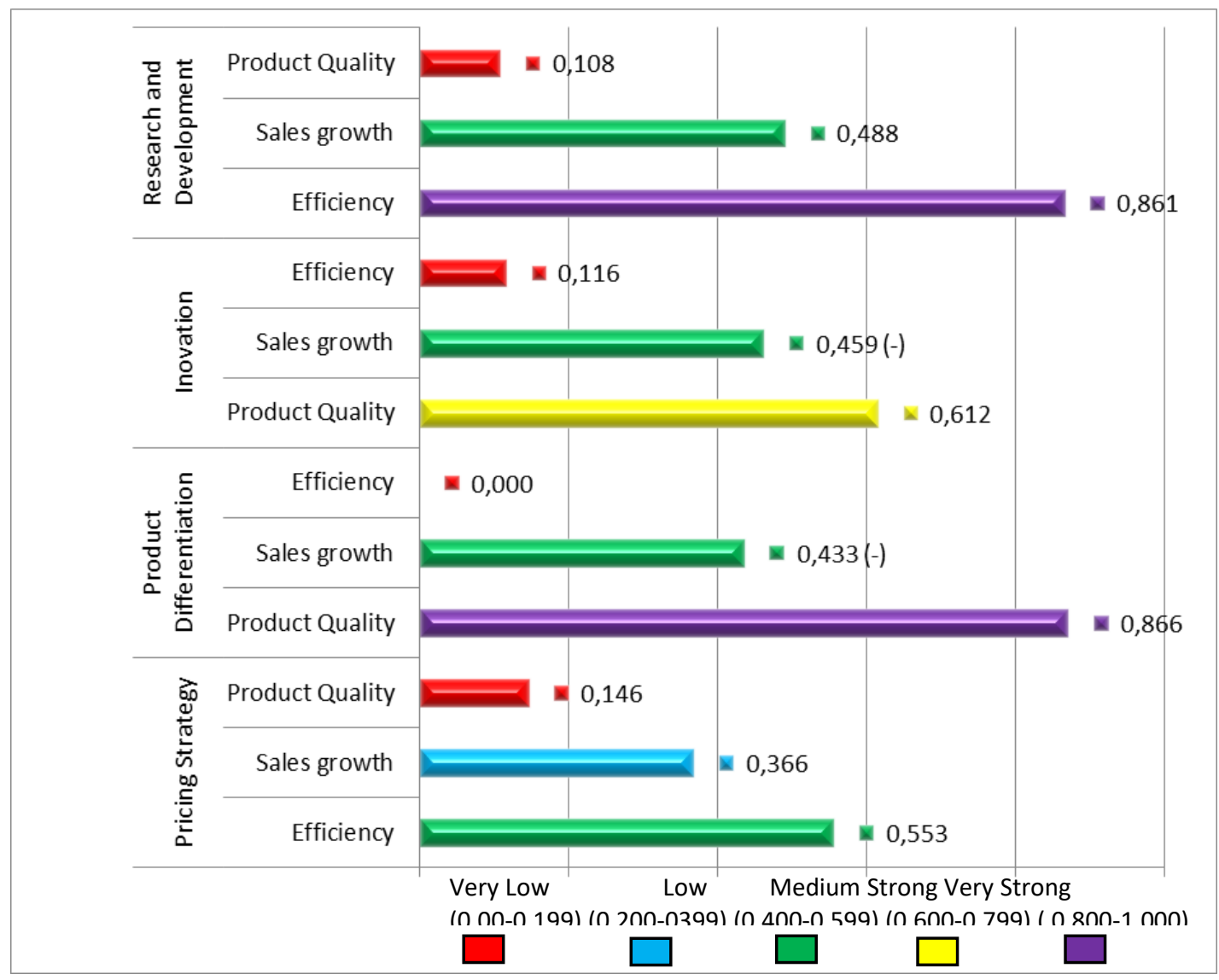

Figure 4 - Correlation between Indicators in Variables of Behavior and Indicators in Variables of Performance

The next analysis is the correlation between the indicators in the variables of structure and the indicators in the variables of performance. Based on the table above, the strongest correlation is that between the indicators of market information (in the variables of Structure) and the indicators of Sales Growth (in the variables of Performance) while the 
lowest/weakest correlation is that between the indicators of Company Size (in the variables of Structure) and the indicators of Sales Growth (in the variables of Performance). As for the lowest/weakest correlation category is the correlation between the indicators of In-and-Out Condition (in the variables of Structure) and the indicators of Efficiency and the indicators of Sales Growth (in the variables of Performance), while the correlation between the indicators of Company Size (in the variables of Structure) and the indicators of Product Quality, the indicators of Efficiency, and indicators of Sales Growth (in the variables of Performance) as well as the correlation between the indicators of Vertical Integration and Diversification (in the variables of Structure) and the indicators of Product Quality (in the variables of Performance).

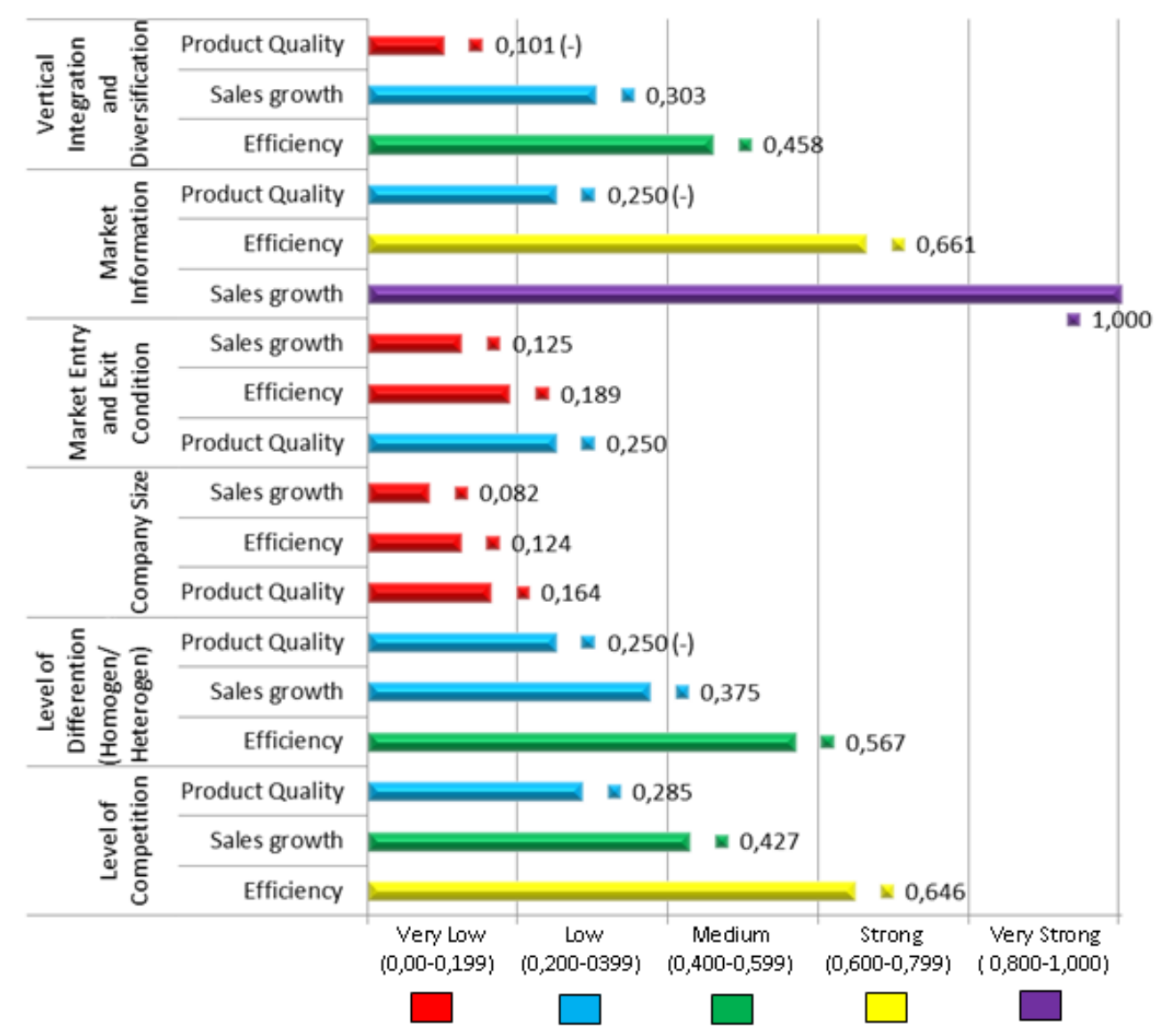

Figure 5 - Correlation between Indicators in Variables of Structure and Indicators in Variables of Performance

After knowing which indicators give the highest contribution and the lowest, what is next is to perform an overall analysis based on the SCP approach; the structure of the market will influence the behavior of the companies in an industry. From the correlation results, it is found that the market structure of the palm oil industry in Riau Province is an oligopoly making it possible to analyze the behavior of each company in the industry in dealing with competition. This behavior can be seen in its competitive to survive. The level of competitiveness of the palm oil companies in Riau Province is very high if seen from the aspect of price strategy. Competition among these companies can also be seen in their research and development sector which they have to create innovations of the palm oil derivatives which in turn influences their production process.

In the variables of Structure, level of product differentiation can be seen. In the correlation between the indicators in the variables of Behavior and the indicators in the variables of Performance is found that product quality is the most crucial as seen in Figure 4 with a significance score of 0.886 . In the correlation between the indicators in the variables of 
Structure and the indicators in the variables of Performance, the efficiency aspect is one of the factors of the companies' competitiveness. Therefore, if a company is capable of being superior in its unique aspects that are difficult to imitate by its competitors such as having low cost productions, being innovative, and being efficient, through those factors, the company can grow its size which becomes what determines its competitiveness.

In the company's behavior variable, the pricing strategy is the highest indicator. Based on the correlation result, it is found that the majority of the palm oil companies have been conducting this pricing strategy. On the level of the company's competitiveness, of the 9 companies which were interviewed, there is a product differentiation and strategy that focuses on the price of the palm oil and this determines the company's longevity. Product differentiation can only be achieved if a company always creates innovations through continuous research and development making it a determining factor of the company's performance. When a company's performance is good, the company can create opportunity to produce superior quality products.

When a company's behavior is in the good state, the company then needs to perform efficiency in all of its aspects, including the quality and sales of its products. The growth of its product sales will be high if its palm oil raw products and their derivatives are of high quality. This is depicted based on the result of the correlation between variables stating that the competitiveness of the palm oil companies is in the quality of the products which are affordable to the consumers.

As a result, to achieve its competitive superiority, and based on the analysis results in in reference to the SCP correlation results, an effective strategy can indeed be implemented. First, the company needs to increase its innovation through product differentiation, research and development. Second, it needs to perform efficiency in several of its activities which can have a risk of extravagance. Third, it needs to explore any market opportunity by improving its information and communication technology; this is to gain all valuable, significant and accurate market information on prices, competitive level, and development of world's palm oil business. Fourth, it needs to increase its sales by setting affordable prices to consumers that cause the company no harm. Fifth, it needs to have synergy with the government, consumers, and capital providers so that it can improve its collaboration strategy which in turn benefits itself.

\section{CONCLUSION}

This study concludes that palm oil companies in the center of palm oil tree plantation industry are in a very tight oligopoly market structure. Effective behavior is required by the companies to be able to show off their superiority. The behavior meant in here is the companies' decision to implement strategies to win against competitors in the industry, as can be seen in the determination of prices and being selective to release products in which each company can show off its distinct superiority.

In the industry of palm oil, technological development has high influence on profit that can be received by a company. This means that if it utilizes modern technology, it can suppress its production costs, create product innovations through research and development, and improve its product quality. Competition among companies is so tough that a very effective strategy is by being able to identify competitors through the structureconduct-performance (SCP) framework. Therefore, companies which are capable of identifying the market and competitors' behavior are also capable of improving their performance in the palm oil industry in Riau Province.

\section{REFERENCES}

1. Almada-Lobo, F. (2016). The Industry 4.0 revolution and the future of manufacturing execution systems (MES). Journal of Innovation Management, 3(4), 16-21.

2. Bain, J. S. (1951). Relation of profit rate to industry concentration: American manufacturing, 1936-1940. The Quarterly Journal of Economics, 65(3), 293-324. 
3. Bain, J. S. (1986). Structure versus conduct as indicators of market performance: the Chicago-school attempts revisited. Antitrust L. \& Econ. Rev., 18, 17.

4. Becker, G. (2014). Structure-Conduct-Performance paradigm. Wiley Encyclopeida of Management. https://doi.org/10.1002/9781118785317.weom080044

5. Capron, L., \& Hulland, J. (1999). Redeployment of Brands, Sales Forces, and General Marketing Management Expertise Following Horizontal Acquisitions: A Resource-Based View. Journal of Marketing, 63(2), 41. https://doi.org/10.2307/1251944

6. Chaiprasit, S., \& Swierczek, F. W. (2011). Competitiveness, globalization and technology development in Thai firms. Competitiveness Review: An International Business Journal Incorporating Journal of Global Competitiveness, 21(2), 188-204. https://doi.org/10.1108/10595421111117461

7. Dirjenbun. (2015). Statistik Perkebunan Indonesia 2014-2016: Kelapa sawit. Tree Crop Estate Statistics of Indonesia 2014-2016. https://doi.org/http://ditjenbun.pertanian.go.id/tinymcpuk/gambar/file/statistik/2016/SAWIT 2014-2016.pdf

8. Febrian, A. F., Maulina, E., \& Purnomo, M. (2018). The influence of social capital and financial capability on sustainable competitive advantage through entrepreneurial orientation: Empirical evidence from Small and Medium Industries in Indonesia using PLS-SEM. Advances in Social Sciences Research Journal, 5(12), 218-232. doi:10.14738/assrj.512.5720

9. Gunawan, I. (2013). Metode penelitian kualitatif. Jakarta: Bumi Aksara.

10. Hauke, J. (2011). Comparison of values of Pearson's and Spearman's correlation coefficients on the same sets of data. Quaestiones Geographicae, 30(2), 87-93.

11. Hoskisson, R. E., Hitt, M. A., Wan, W. P., \& Yiu, D. (1999). Theory and research in strategic management: Swings of a pendulum. Journal of Management, 25(3), 417-456. https://doi.org/10.1177/014920639902500307

12. Kaur, G., \& Mantok, S. (2015). Role of Market Orientation and Competitive Advantage in Firm 'S Performance. International Journal of Applied Business and Economic Research, 13(3), 1229-1241.

13. Kim, S., Lee, J., Yu, K., Kim Jean Lee, S., \& Yu, K. (2004). Corporate culture and organizational performance. Journal of Managerial Psychology, 19(1), 340-359. https://doi.org/10.1108/02683940410537927

14. Kraciuk, J. (2018). Changes in the added value chain in economy 4.0. In Economic Science for Rural Development Conference Proceedings.

15. Lasi, H., Fettke, P., Kemper, H.-G., Feld, T., \& Hoffmann, M. (2014). Industry 4.0. Business \& Information Systems Engineering, 6(4), 239-242.

16. Lilliefors, H. W. (1967). On the Kolmogorov-Smirnov test for normality with mean and variance unknown. Journal of the American Statistical Association, 62(318), 399-402.

17. Loecker, J. De, \& Goldberg, P. K. (2013). Firm Performance in a Global Market. The Annual Review of Economics. https://doi.org/10.1146/annurev-economics-080113104741

18. Mukherjee, A., Kamarulzaman, N. H., Shamsudin, M. N., \& Latif, I. A. (2015). Agility barriers analysis in the Malaysian Palm Oil industry. International Journal of Supply Chain Management, 4 (1), 60-64. ISSN: 2050-739

19. Musianto, L. S. (2002). Perbedaan pendekatan kuantitatif dengan pendekatan kualitatif dalam metode penelitian. Jurnal Management and Kewirausahaan, 123-136. https://doi.org/10.9744/jmk.4.2.

20. Obado, A. J. (2008). Competitiveness of Indonesian Crude Palm Oil and the Effect of Export Tax on its Performance in the World Market. Bogor Agricultural University.

21. Porter, M. E. (1985). Competitive Advantage. Competitive Advantage: Creating and Sustaining Superior Performance. https://doi.org/10.1182/blood-2005-11-4354

22. Rasiah, R., \& Shahrin, A. (2006). Development of Palm Oil and Related Products in Malaysia and Indonesia. University of Malaya.

23. Schmalensee, R. (1989). Inter-industry studies of structure and performance. Handbook of Industrial Organization, 2, 951-1009. 
24. Smith, R. (2008). Aligning Competencies, Capabilities and Resources. The Journal of the Industrial Research Institute, (September-October), 1-11. https://doi.org/10.1080/08956308.2008.11657525

25. Stock, T., \& Seliger, G. (2016). Opportunities of Sustainable Manufacturing in Industry 4.0. Procedia CIRP, 40, 536-541. https://doi.org/10.1016/j.procir.2016.01.129

26. Sugiyono. (2010). Statistika Untuk Penelitian. Bandung: Alfabeta.

27. Teece, D. J., Pisano, G., \& Shuen, A. (1997). Dynamic capabilities and strategic management. Strategic Management Journal, 18(7), 509-533. https://doi.org/10.1002/(SICI)1097-0266(199708)

28. Weerawardena, J., \& Mavondo, F. T. (2011). Capabilities, innovation and competitive advantage. Industrial Marketing Management, $40 \quad$ (8), $1220-1223$. https://doi.org/10.1016/j.indmarman.2011.10.012

29. Weiss, L. W. (1979). The Structure-Conduct-Performance Paradigm and Antitrust. University of Pennsylvania Law Review. https://doi.org/10.2307/3311794 